\title{
HOW CHILDREN'S LITERATURE IS TRANSLATED: SUGGESTIONS FOR STYLISTIC RESEARCH USING PARALLEL CORPORA
}

\author{
Michael Toolan \\ University of Birmingham \\ Birmingham, UK
}

Abstract

This paper aims to offer some points of orientation for anyone interested in carrying out research into TCL (the Translation of Children's Literature) from a translational corpus stylistic perspective. In order to achieve that, I first offer $\$$ me \& neral $\boldsymbol{b}$ servations b out $\$$ ylistics and $\mathrm{d}$ rrative Analysis. Then, I briefly describe the corpus-based system us ed to show the potential significance of this proposal for a research area within TCL, which has a chiefly empirical character. Next, I make some suggestions of topics that could be further explored by people interested in this particular area of study. Finally, while emphasizing the unprogrammable situated determinacy of all communication (including translation), I offer some observations about how to proceed with a translational corpus stylistic approach and its promise of benefitting future research on TCL.

Keywords: Keywords: Translation of Children's Literature (TCL); corpus stylistics; narrative analysis

"Has an undergraduate degree MA in English Language and Literature from Edinburgh University; and a DPhil on William Faulkner's style from Oxford. Is professor of the University of Birmingham English Departament since 1996. His e-mail address is m.toolan@bham.ac.uk. 


\section{Translational Corpus Stylistics and Children's Literature}

In recent years there has been a surge of academic interest in the study of children's literature in translation. As a newly-emerging research area, however, Translation of Children's Literature (TCL) has still many tantalizing secrets to be uncovered and faraway places to be explored. Moreover, it is interesting to note that the body of academic research carried out so far in this particular area seems to be dominated by a focus on the contexts of production and reception in which translated texts for children are generated (see Coillie \& Verschueren, 2006 and Lathey, 2006).

Despite the acknowledged importance of context in the study of translational phenomena (see Baker, 1999, p. 285), it seems that studies involving the investigation of significant linguistic patterns and features are less frequent in the translation of children's literature. This state of affairs can be partially explained by the fact that "the contexts in which children's literature is produced and disseminated are usually dominated by a focus on content and theme" and as a result "the language of children's literature receives little explicit attention" (Stephens, 1999, p. 56).

Stephens (ibid.) points out that this kind of research orientation in children's literature views language as a "transparent medium" from which content and theme can be extricated. Consequently, research of this kind is usually focused on "what" is conveyed through language (content) rather than "how" it is conveyed (form). In this sense, I would like to argue that if there is to be any serious and genuine attempt to investigate translational phenomena in children's literature, then there must be some concomitant engagement with the language of this particular literary form. After all, language is the main channel through which the contents and themes of children's literature are given expression and without language these contents and themes could not be realised.

One branch of Translation Studies concerned with the study of languagechoices in translated literary texts is called "translational stylistics" (Malmkjær 2004). This is intended to contribute to writer-orientated studies of translated texts (where the writer is the translator), and stipulates that the translated text be seen in the context of its source text. Being primarily concerned with the translating writer's motivation, it argues the need for the analyst to search "for patterns in the relationships between the translation and the original text” (Malmkjaer 2004: 20). A kind of parallel corpus, where Hans Christian Andersen's Den lille Pige med Svovlstikkerne ('The Little Girl with the Matches') is aligned with a word-for-word English gloss and then the near-contemporary translation by Henry William Dulcken, helps Malmkjaer to identify patterns of sentimentalising differences and evasions in the Dulcken translation. Dulcken's choices can then be related to his possible motivation, albeit more speculatively.

The focus of the present article is somewhat different, but again exploits the availability of parallel corpora in order to evaluate subtle but important stylistic choices in an English original and in Portuguese and Spanish translations. A 
slightly different marriage of stylistics, translation, and parallel corpora is involved, which looks to stylistic analysis to provide an established linguisticallyinformed metalanguage which can help analysts to identify significant linguistic patterns and features, in source or in translation (cf. Simpson 1993: 4). A pattern is a repetition, and there is no pattern that is not a repetition-which is why in my stylistics I have latterly emphasised the role of repetition, in both poems and narrative fiction (Toolan 2012, 2015b, 2016). Stylistics is a hybrid or interdiscipline (as Leech 2008 compellingly argues) deployed in the analysis of a variety of literary and non-literary genres, including the study of written narratives of all kinds; the relations between stylistics and narrative analysis are such that a linguistic stylistic approach can be regarded as one (of numerous) perspectives which can illuminate the structures, techniques and effects of narratives.

A stylistic approach to classic children's novels, whether this is the Artemis Fowl, Harry Potter, or Narnia series, need be no different in essentials from the stylistic approach to any literary text. It will be a textual analysis and a commentary articulated in linguistic terms, and will assume that the descriptive and explanatory systems of one linguistic model or another (formal, functional, cognitive, etc.) is an effective way of enhancing an understanding of how the text works. But who is this I, whose understanding may be enriched? In principle it is an entirely open group: ordinary readers (child or adult), teachers, writers, translators, or scholars.

Today there are many hyphenated sub-types of stylistics, which are themselves by no means mutually incompatible (e.g., cognitive stylistics or poetics, but also corpus stylistics, pragmatic stylistics, critical discourse stylistics, ecolinguistic stylistics). More unites these than separates them, since linguistic categories and methods take pride of place in all of them: the language of linguistics is used to understand the language of literature. A key proviso, however, is that the linguistics stylistics uses, and its consideration of particular original or translated texts, must be contextualised. Like translators, stylisticians recognise the inescapable pressure of context, or rather contexts: for example, the many contexts within which the Harry Potter novels emerged, and the reasons and expectations shaping a São Paulo-resident nine-year-old schoolboy's sitting down to read Harry Potter e a Pedra Filosofal. An awareness of the inescapability of contextualisation as framing the production and reception of a Harry Potter novel, including the stylistic analysis of these, is also a recognition that form, meaning, value and interpretation are open to change with change of reader, despite the degree of convergence or similarity, among diverse readers' reading of a single text, which makes the idea of a shared language and textual analysis possible.

Finally, stylistic analysis of text aims to be explicit and accessible: it tries to talk about texts in terms which are clear and comprehensible to all. So a "marriage" with corpus materials and tools is inherently felicitous. There is a strong "WYSIWYG" tendency with corpus analysis, and this is entirely congenial to stylisticians, whose goal is that every descriptive or explanatory claim is backed 
by inspectable evidence and even, occasionally, possibilities of falsification: pattern or form $\mathrm{X}$ has effect $\mathrm{Y}$ (in the text or on its readers) because with $\mathrm{X}$ removed readers report absence of the $\mathrm{Y}$ effect.

But can texts be taken to pieces in the way stylistics threatens to do? Doesn't one lose the real experience of the forest, by logging the trees one by one? In looking so closely into the lineaments of a text is the analyst looking too closely, or "too curiously" (in Hamlet's sense of the phrase)? For stylisticians, like translators and writers, the answer must be No, on the grounds that in enduring literature and its translation a perfectionism can be assumed to be operating in the authors and translators: both kinds of writer have aimed to realise the work as completely and effectively as possible. A quotation from the Nobel prizewinner Alice Munro reminds one of this authorial care over every last detail, which justifies a parallel corpus stylistic analysis of some of those many details (e.g., the fact that, between the New Yorker magazine and book-form publication of one of her stories a few months later, Munro went to the trouble of changing a single mention of a cheque for a thousand dollars to a cheque for one thousand dollars (Toolan 2015a). There is a revealing moment in a recent interview with Munro when the interviewer asks if she ever goes back to read her earlier books and Munro replies:

No! No! I am afraid to! No, but then I would probably get a terrific urge to change just a little bit here, a little bit there, and I have even done that in certain copies of my books that I would take out of the cupboard, but then I realize that it doesn't matter if I change them, because it's not changed out there....

This Munrovian revisionism confirms Munro's stylistic perfectionism, which in turn is powerful justification for detailed corpus stylistic study of enduring classics such as the Chronicles of Narnia in their Portuguese (and Spanish, etc.) translation alongside the English original.

\section{A brief description of COPA-TRAD - A Translational Parallel Corpus}

COPA-TRAD (copa-trad.ufsc.br) is a Portuguese-Spanish-English parallel corpus system project conceived and developed at Universidade Federal de Santa Catarina (UFSC) with a focus on translation research, teaching and practice. Recently, this project was awarded a Newton Fund Advanced Fellowship Scheme by the British Academy, which allows members of the project team to visit the University of Birmingham and present the project while further developing its possible applications, especially to Narrative Studies and Corpus Stylistics, assisted by English Language staff at Birmingham. The main tool provided by COPA-TRAD is a parallel concordancer, COPA-CONC (i.e. a tool that shows every occurrence of a search word/expression in a source language along with 
its translations in a target language). This tool enables the user to investigate the practices of professional translators by adjacent display of specific words and phrases in a source text and its translated versions. Additionally, COPA-CONC allows for the comparison between human translation and machine translation by the integration of two renowned machine translation systems into this particular tool (Google Translate and Microsoft Translator). The COPA-TRAD research project is participating in the Google Translate University Research Program, which has allowed COPA-TRAD to include the Google Translate Application Programming Interface (API) in its system. The potential of this particular tool for investigation of similarities and differences between human and machine translation is considerable.

COPA-TRAD currently comprises three sub-corpora; Children's Literature (COPA-LIJ), Adult Literary Texts (COPA-LIA), and Meta-Discourse in Translation (COPA-MDT), with certain tools still under development: a monolingual concordancer, wordlist and smart search functions, and a DIY Tool that allows for the user to create their own small scale corpora and analyse them automatically.

In the next section, I offer some directions for those interested in carrying out research into translation of children's literature from a narrative perspective that is based on a corpus stylistic approach.

\section{Directions for Future Corpus Stylistic Research on the Translation of Children's Narrative Literature}

\subsection{Keywords}

By the term "keywords" corpus linguists refer to those words in a text whose frequency, by comparison with these same words' frequency in a large (and genre- and register-appropriate) reference corpus used for comparison, are markedly high. The latter are known as positive keywords, and often reflect what a text is "about"; the keyword calculation will also identify strikingly rare uses of particular words in a text, relative to the reference corpus, and these "negative keywords" are often of interest too. Grammatical items are infrequently key, but revealing when they are. But in written narratives, the most marked keywords tend to be proper names, and then the prominent elements in the material setting of the story. Keywords can be rapidly identified, using Antconc, Wmatrix, WordSmith Tools, or a similar easily-available textanalysing tool; thereafter, further translation-oriented kinds of research are greatly facilitated by COPA-TRAD.

For instance, in a matter of seconds Wmatrix analysis of a bare txt version of The Eternity Code reports its top (most "key") keywords. Besides a few grammatical items (I, you, no, it, what), the very most prominent (disproportionately frequently occurring) items are all main characters' names--Artemis, Holly, Spiro, Butler, Mulch, Juliet, Foaly, Fowl, (the) Cube, Loafers, LEP, Chips, Needle, etc. But after 
these come the story's top lexical keywords, content words other than characters' names, and in descending order of keyness these are: fairy, dwarf, bodyguard, security, helmet, screen, kid, visor, and foil. As will emerge in the discussion below, the first two of these are somewhat name-like too; but most of the remainder of these most key words are strikingly to do with conflict, attack and defence, and surveillance. Some of these words, viewed in isolation, might suggest peaceful domesticity (e.g., the foil used in oven cooking), but a glance at the KWIC lines for confirms that the visored helmets are high-tech para-military equipment while the foil fulfils a concealment function, usually immediately preceded by the clipping cam, for camouflage: cam foil occurs 11 times, camouflage foil just 7 times. There are some clear contextual trends as to when the text has camouflage foil and when it has cam foil: only the former is used in lengthy narrative sentences, quite often preceded by a sheet of; only the latter is used in any direct speech mentions (e.g.,'I'll just have to huddle close together behind the cam foil,' said Juliet), but it is also used in short active narrative sentences: Butler lifted the cam foil, concealing himself completely. So cam foil associates with directness, and the insider's perspective.

How does the Portuguese translation handle this cam/camouflage distinction in the source text, and its preponderant use of the clipped, "insider-jargon" form? COPA-TRAD shows that no counterpart strategy is attempted: cam foil and camouflage foil are invariably translated on all occasions as tecido de camuflagem. As for the Spanish translation, here I find tela metálica de camuflaje on the first mention, and tela de camuflaje for every subsequent use. Things are made more complicated by the fact that both tecido, in the Portuguese, and tela, in the Spanish, have various other senses besides "foil", and are used in these other senses in their respective texts, whereas foil, despite having other senses as noted above, is not used in those other senses in the original English. What I can conclude is that an indexical registral alternation in the original text has not been maintained-and perhaps could not have been maintained, in anything approximating "naturalness"-in these Portuguese and Spanish versions. This is one of very many prominent kinds of idiom-, register-, or usage-based contrasts that COPA-TRAD, allied with partner corpus analytic tools, can rapidly draw to the researcher's attention.

Turning back to the very most key of the lexical keywords, $d w a r f$ and fairy, like the other top lexical keywords both of these occur fifty or more times in the novel, with a keyness score (using the BNC's "written imaginative" comparator or reference corpus) of over 100. Using COPA-TRAD or Wmatrix, all the KWIC (Key Word in Context) concordance lines for, e.g., fairy, which occurs as many as 83 times, this reflecting the obvious fact that the story involves fairies. Rapid scrutiny of the KWIC lines reveals that fairy is overwhelmingly used as modifier of a following head noun and preceded by a determiner (mostly the). As for those head nouns, those items occurring in what corpus analysts call the R1 position, immediately following the word of interest, the KWIC format shows that alongside more familiar collocations, such as fairy magic, fairy girl, are a number 
that are decidedly unexpected-but which indicate what the narrative centrally involves. Thus the commonest collocate occurring immediately to the right of fairy in this novel is not magic, folk, or people, but technology (9 occurrences of fairy technology), with other amusingly unexpected phrases including fairy SWAT team, fairy surveillance and fairy black market. These are fairies, but not quite as I know them from traditional children's tales. COPA-TRAD shows that the Portuguese translation almost always translates the phrase fairy technology as a tecnologia do povo das fadas (literally 'the technology of the fairy people). [Is this a little awkward? Is 'people'/povo more or less obligatory Lincoln? ]

As for $d w a r f$, here is a random sample from the 57 instances of $d w a r f$ in the text (includes $1 d$ warf-sized), as retrieved and displayed in KWIC format by Wmatrix:

1. Chicago ? Jon Spiro sent you?' The dwarf shook his head. 'Possibly, but not

2. e no idea that I am an actual fairy dwarf; they think I' $m$ simply the best ca

3. Mulch, who was apparently a fairy dwarf. This was getting weirder and weird

4. . Or should I say Mulch, the fairy dwarf ?' Mulch swallowed the halfchewed

5. 'd eaten bigger. A quick burst of dwarf gas should be enough to propel him a

6. heard Mulch say that he was a fairy dwarf. " No problem, 'said Foaly. 'Do

7. ovely view of his rear end. In the dwarf world, presenting your behind was $t$

8. . 'I said move it!' repeated the dwarf, stressing the point with a firm sh

9. lch into Pex's gigantic arms. The dwarf kept talking, even as he was being

10. mention two humans, an elf and a dwarf assuming the dwarf survived Pex and

11.s, an elf and a dwarf assuming the dwarf survived Pex and Chips. The vault d

12. upwards using the last vestiges of dwarf gas to propel him from his hole . Ho

The concordance lines reveal that $d w a r f$ functions most of the time to name a particular character, Mulch, when it functions as a head noun and is preceded by the definite article (the dwarf); but elsewhere dwarf is a modifier of a head noun to its right, as in dwarf gas, dwarf hair, dwarf world, dwarf female, dwarf rock polish, etc., suggesting that it denotes an entire ethnic group or culture (of which Mulch is a story-significant member). The KWIC evidence also draws attention to the frequent collocation of fairy and dwarf, in that order (there is no instance of dwarf fairy in the novel), which in the context of the larger set of mentions of dwarf may suggest that fairy denotes some exceptional attributes of, here, an otherwise unexceptional group, dwarfs. In this novel, a fairy dwarf seems to denote a "magic-wielding dwarf", with the added suggestion that all the dwarfs here wield magic. This ambiguity or polysemy is not captured in the 
Portuguese version, where the translation of fairy $d w a r f(s)$ is Anão/Anões do povo das fadas, "dwarf(s) with fairy powers". In the Spanish, I find un enano del mundo del subsuelo and un enano del subsuelo: "a dwarf from underground, from middle earth") Suffice it to say, $d w a r f$ would appear to be quite a challenging item to translate, in these complex circumstances. And these are predictions the analyst can frame, and information they can extract, even without having read the novel, merely drawing on concordance and collocational evidence.

In the Portuguese translation $d$ warf is standardly translated as anão $(O$ anão), and in the Spanish as enano (el enano). But whereas Wmatrix finds 57 instances of $d$ warf and 9 occurrences of $d$ warfs in the English version, it finds 52 instances of enano, 15 of enanos ('dwarfs'), 1 of enana ('female dwarf') and 1 of enanitos ('little dwarfs'?) in the Spanish version. In the Portuguese version there are 52 instances of anão and 10 of Os anões (where the Os can be non-specific, denoting dwarfs in general). Already there is some divergence here, prompting the question why enanos is more frequent in Spanish than anões is in Portuguese or dwarfs is in English. A COPA-TRAD-style parallel concordancing of the 15 Spanish instances of enanos, against the (non-uniform) English translations, could accelerate such an enquiry; in fact it is an example of how the new technology makes "askable" certain questions in stylistics and translation that might have been too burdensome to pursue in the pre-digital era.

\subsection{Emotion words and Reader "Immersion"}

Stylistics has a growing interest in the emotions: how they are portrayed in literature, how they affect readers' responses, and how reader engagement with the story world seems very often to involve a kind of mirroring, in the reader's emotions, of the emotions represented or provoked by the text. The interest in emotions is especially strong in cognitive stylistics, which emphasises how the use of language is an "embodied" process and the reader a "bodied" interpreter responding to the representations of similarly embodied characters in fiction. If a text is in part valued because of the way it triggers particular complex feelings of fear, sorrow or joy in a reader, then linguistic contribution to that triggering merits careful study; and if a translation of that text fails to elicit comparable emotions, and is in fact a bit of a "damp squib", it is of stylistic and translational interest to identify the linguistic sources of that misfiring.

A beginning can be made, using COPA-TRAD, by noting a text's "emotion words"-e.g. all its lexis semtagged by Wmatrix as "fear" words. In The Eternity Code, these include afraid (4), scare (1), scared (3) among others. Clicking on any of these to identify the semtag to which it is assigned reveals that they are all automatically classified as in category E5-. All the E categories are emotionrelated, and E5- is classified as "Fear/shock". Armed with this knowledge, one can reverse the search, and ask Wmatrix to list all words that it automatically classifies as E5-. This returns 53 words, which is approximately $0.08 \%$ of the 66k-word text: The Lion, the W and the W, with 49 E5- fear/shock words in a 
36k word text, has a percentage rather higher, at approximately $0.14 \%$ (highest frequency of these is afraid, 16 instances). Of the Eternity Code items, some are more truly fear- and shock-denoting than others, the more frequent (more than 2 instances) being alarm (8), stunned (4), afraid (4), horror (4), scared (3) and stun (4). Now of course there is no guarantee that these "scary" words are indeed the cause of the most frightening moments in the narrative, or of the greatest moments of unease in the reader. It is certainly possible for sentences without a trace of E5- vocabulary in them, in suitable context, to convey fear and provoke fearful emotions in a reader. But corpus methods have no obvious way of identifying the latter passages, and, on the other hand, it may be that E5- words tend to appear at those moments in narratives where fear is involved (in the text and then in the reader). A closer look at the contexts of the above "fear" words may confirm or disconfirm this.

A first useful step is to return to Wmatrix to see all 53 E5- (fear, shock) words in their immediate context, i.e., a concordance of them. This confirms that there's nothing genuinely fear-related about a good number of the 53 items; one use of scared comes in this direct speech from Artemis: "I never tell anybody exactly how clever I am. They would be too scared." Such ironical assertions of fear are frequent in the direct speech instances. Many of the occurrences of alarm concern a fire alarm, a security alarm, alarm boxes, and so on. The uses of stunned are close to the core emotional sense, but mostly denote "amazement, incomprehension" rather than fear. Afraid is a little more promising-but it is almost entirely within DS, and one must set aside the formulaic uses of I'm afraid (that) meaning a not-necessarily-sincere "I'm sorry that". And horror, too, is only used in knowing and reflexive ways, that make fun of the very idea of horror: the mole-like Mulch suggests to his gormless would-be killers that they bury him alive, and one of them is doubtful about this: "Buried alive?! That's like in that horror movie. Y'know, the one with all the horror.” In sum, all these examples serve as powerful evidence for arguing that there is very little place for "genuine" fear in The Eternity Code, as might be expected from the genre to which it belongs. In that genre, no-one of importance is every seriously at risk, no-one of importance carries a chronic or irrevocable defect or inability. There are few if any moments of genuine and deep-seated contempt, disgust, revulsion, or grief.

What about some of the other emotion-word semantic categories in Wmatrix, and the instantiations identified automatically in the text of The Eternity Code, such as those for joyful and sad words, E4.1+ and E4.1-? These too (E4.1+ and E4.1-) are unreliable guides to genuine emotions. The episode above about burying Mulch alive is followed by the killers speculating that Mulch "musta been crying" when they buried him (when in fact he is shaking with laughter (at this point $3 \mathrm{E} 4.1+$ items, describing Mulch, occur: laughing $\mathrm{x} 2$ and laugh).

A quick search within the COPA-TRAD selection of books shows that if I wish to examine translations of angry, and sad/miserable, then the Narnia books and the Harry Potter books (e.g., Harry Potter and the Prisoner of Azkaban) are a much richer source than the Artemis Fowl books. The Wmatrix semtag results 
for The Lion $W W$ show high absolute frequencies for E2+ like (60), E3- violent/ angry (60), E4.1+ happy and E 4.1- sad (64 and 67 respectively) and E5-, fear/shock (49). All E-prefix semtagged words in The Lion, i.e. all its seemingly "emotion"related lexis, add up to $1.13 \%$ of the entire text. The counterpart E- figure for The Eternity Code is $1.08 \%$, and the dominant sub-categories are E3-violent angry and E4.1+ happy and, to a lesser extent, E2+ like: is, in emotional terms, the world of The Eternity Code seems to be mostly a violent but happy-which perhaps would especially appeal to the imaginations of younger teenage boys.

\subsection{Mental process verbs: thought and felt}

Two of the most interesting-and standard-verbs used in English literary narratives to introduce reports of a character's inward reactions are think and feel (typically, given past tense narration, in forms like she thought with adjacent direct or indirect internal discourse (DT or IT) and he felt. Postponing discussion of $s / h e$ felt, I turn first to $s / h e$ thought. In the English original of The Eternity Code there are 60 instances of thought, a few of which, randomly selected, are shown below:

1. nickname Loafers himself, because he thought it sounded more Mob-like than Aloysius

2. $s$ it ? 'Of course it is, moron, thought Inky . I'm sticking a needle in yo

3. Do n't let it show on your face, thought Mulch. Do n't let them see . 'No.

4. nk on his feet. If Carla Frazetti thought he was n't up to the job, then the

5. which was pretty pathetic when you thought about it. He had to take the job ,

6. Frazetti knew he was gone. Mulch thought about it seriously. This kind of $t$

7. his eyes from the road. 'Nope. I thought you were the head honcho here. Pla

8. oafers had to open a window at the thought of it. 'OK. You come get me. But

9. is a dangerous man, Artemis . I thought you would have learned that . "I

10. Mo talking in his earpiece. At first he thought the monkey was speaking to him, but...

Working with all 60 instances, in order to focus on projecting mental process verb uses, one must first strip out the non-verbal instances (perish the thought; he held on to a single thought), along with a few where no clear accompanying reported discourse can be identified (e.g., Mulch thought about it seriously). This leaves approximately 50 instances of thought in genuinely discourse-reporting uses (some of these are within direct speech, e.g., "Jon Spiro is a dangerous man, Artemis. I thought you would have learned that").

When one examines the the Portuguese translations of these 50 instances, nearly all are found to use, for thought, suitably inflected forms of the verb pensar 
(pensei, pensava, pensou, pensavam). Where pensar is not used becomes of interest. Some of the instances where something different is used seem to arise where the original is itself somewhat idiomatic: thus Who would have thought it? is translated as Quem imaginaria?

But most of the minority of occasions where pensar is absent, I find a form of achar being used:

1. because he thought it sounded more Mob-like than Aloysius.

2. porque achava que parecia mais coisa da Máfia do que Aloysius

3. If Carla Frazetti thought he wasn't up to the job....

4. Se Carla Frazetti achasse que ele não estava à altura do serviço

5. At first he thought the monkey was speaking to him

6. A princípio achou que o macaco falava com ele

7. I always thought the world could not be changed.

8. Sempre achei que o mundo não poderia ser mudado.

9. People thought it was easy being him.

10. As pessoas achavam que era fácil ser ele.

11. There was this Irish kid who thought he was ready for the big time.

12. Era uma vez um garoto irlandês que achava estar pronto para se dar bem.

This generates one simple but interesting question for people translating between English and Brazilian Portuguese narrative texts:

Why, where the original simply used thought, does the Portuguese translation on a significant number of occasions (10\% instances) opt instead for achar rather than the default pensar?

An internet search gives help-of a sort. The first hit is a question on a language website which asks: What's the differents [sic] between 'Achar' and 'Pensar'?, with the prefatory observation that the enquirer notes achar is more commonly used https://www.italki.com/question/88316. That immediately prompts the question whether achar is more a +Spoken choice than pensar. But the internet answers are themselves revealingly confusing and inconsistent, with contributors correcting their ideas as they go along, and one commentator concluding that the whole business of capturing the difference betIen achar and pensar is "very trick"! But achou can also be used to mean I found/discovered (e.g., car keys or other buried treasure). In its "think/thought" sense it sometimes seems to mean "I believed, supposed, guessed, speculated--but wasn't sure-that" whereas pensou seems to denote ideas that have been more definitely decided upon (possibly mistakenly).

What about the Spanish translation? Is a second verb, denoting a more specific kind of thinking/judging/believing/imagining, present in the English to Spanish data? And if a $2^{\text {nd }}$ verb is used, is it used for very much those textual instances where the Portuguese switched to achar? All these questions are much easier to address with a tool like COPA-TRAD. What emerges if all those passages are examined where the Portuguese uses a past tense form of achar (where it 
means "thought", not discovered, etc) is that the Spanish version also often opts for something other than the "default" pensar verb, namely creer:

At first he thought the monkey was speaking to him ...

A princípio achou que o macaco falava com ele...

Al principio creyó que el mono le estaba hablando...

People thought it was easy being him.

As pessoas achavam que era fácil ser ele.

La gente creía que era fácil ser él.

There was this Irish kid who thought he was ready for the big time.

Era uma vez um garoto irlandês que achava estar pronto para se dar bem.

Había un niño irlandés que se creía preparado para el estrellato.

In the local context of translation The Eternity Code, thought (as projecting past tense thought-reporting verb) is standardly translated as by forms of pensar in both Portuguese and Spanish, but in a minority of cases Portuguese uses achar and those same minority cases are mostly translated by creer in Spanish. This matching of achar with creer (specifically in $X$ thought (that) $y$ contexts) is an interesting finding from the parallel corpus data which merits further study.

There is no denying that this is all, in a sense, amateur: why not simply consult something like Whitlam 2010, Ganho \& McGovern 2004, or Davies \& Preto-Bay 2007? But that may divert attention from the source and target texts (here, The Eternity Code/O Codigo Eterno), and in a sense removes the responsibility and blocks the engagement of the translator, reader, or language-learner. Parallel corpora, alongside reference corpora, of course are not sufficient for all tasks, but they can facilitate an empowering kind of Data Driven Learning (and discovery), in the spirit of Tim Johns (e.g. Johns 1991). Of course thought and its translation partners in Portuguese and Spanish is just the tip of the iceberg.

\subsection{Free Indirect Speech and Thought}

The much-discussed and quintessentially (but not exclusively) literary techniques known as Free Indirect Discourse (discurso indireto livre, el estilo indirecto libre) expresses a character's speaking or thinking within the narrative text and without anything as overt as a reporting clause, quotation marks, first person pronouns, or present tense. It requires an attentive reader, who realises that the narrator is not reporting from their detached perspective, but it rewards such a reader with a heightened alignment with the character whose words are thus relayed. In The Eternity Code a number of characters have their private thoughts articulated through FID (more specifically its sub-type FIT: free indirect thought). I will look at just two of the many places where it is deployed.

The first comes in the course of the "surgery for morons" episode where Dr Holly Short, at Artemis's request and coached at a distance by Foaly who instructs her through her earpiece, uses cryogenics and fairy magic surgery to revive the 
lifeless and deep-frozen Butler. The quoted passage begins with Foaly's direct speech instruction to Holly; the phrases I take to be FIT have been underlined:

"Get in there. The magic is spreading up his spinal column. Hold his head still for the healing, or any damaged cells could be replicated. And once something's been healed, I can't undo it."

Great, thought Holly. Hold Butler still. No problem. She battled her way through the debris, cold-pack crystals impacting against her visor.

In the given context, it is clear that Hold Butler still is Holly's repeating, to herself rather than out loud, of Foaly's instruction to her; and particularly since it comes after the sarcastic Great, Holly's No problem must be similarly interpreted as her ironic comment on a task which she regards as difficult, and easier said than done.

Our second example comes close to the end of the novel, and in fact comprises two brief near-adjacent moments of FIT, attributable to different characters, indeed antagonists. The example also shows how FIT is often prepared for by a "preparatory" mental process construction such as she knew, he thought or even they felt. Juliet has just disabled the villain Spiro's bodyguard, Blunt, with her magic jade ring, but two more of Spiro's lackeys consider intervening (FIT passages again underlined):

Blunt was now out of the game. Juliet had expected to feel some satisfaction, but all she felt was sadness. There was no joy in violence.

Pex and Chips felt they should do something. Perhaps disabling the girl would earn them a bonus from Mister Spiro? They circled Juliet, fists raised.

That there was no joy in violence is not a narratorial observation directed at the reader, but a free indirect articulation of what, in her sadness, Juliet thought. But immediately the reader must switch from "reading Juliet's mind" to reading those-or the group mind? - of Pex and Chips. Again their FIT speculation, only thought in common rather than publicly spoken to each other, is prefaced by a felt verb: "disabling the girl" in the hope of a bonus is the something they felt they should do. But there is no articulation of a viewpoint internal to Pex and Chips in the next sentence: we are viewing them, and Juliet, from outside, like any neutral bystander.

These are two of the very many quite fleeting passages of Free Indirect Thought in The Eternity Code, briefly aligning the reader with the innermost reactions of one or another of the main characters. How Ill can these be conveyed in translation? Again, parallel corpus presentation enables quite a rapid comparative assessment. Just the FIT phrases, with immediately preceding text, are given below in English again, together with the Portuguese and Spanish translations. 
"Hold his head still...." Great, thought Holly. Hold Butler still. No problem. "Segure a cabeça dele ..." Fantástico, pensou Holly. Segurar Butler imóvel. Sem problema.

"Sujétale quieta la cabeza..." Estupendo, pensó Holly. Mantener quieto a Mayordomo, ningún problema.

Whether the Portuguese choice here is entirely satisfactory may be debated. While the English FIT echo of Foaly's words changes his head to Butler, the Portuguese does this but also changes the form of the verb, from the imperative to the infinitive, arguably necessarily. It also adds imovel, overall making it much less FIT-echoic of Foaly than "less grammatically correct" Segure a cabeça dele or Segure a cabeça dele imóvel would have been. The Spanish makes even more changes, away from ironic echoing, with gender-agreement also enforcing a change from quieta to quieto (simply repeating Sujétale quieta la cabeza would surely have been an option or, a minimal adjustment, Sujétarle quieta la cabeza; or, changing Foaly's initial instruction: "Mantenle quieta la cabeza..." Estupendo, pensó Holly. Mantenle quieta la cabeza, ningún problema.).

all she felt was sadness. There was no joy in violence.

[Juliet] mas só sentia tristeza. Não havia alegria na violência.

lo único que sentía era tristeza. No había ningún tipo de regocijo en la violencia.

On this occasion, since the observation attributable to Juliet takes the form of a gnomic or generic existential sentence, both translations are "FIT-compliant", although the Portuguese is more effective in being source-comparably brief, and in its use of a simple antonymic partner to tristeza, just as the original matched sadness with joy. Like the Portuguese, the Spanish could have used the simpler alegría (overtones of 'delight') or, probably better, placer (overtones of 'pleasure') rather than regocijo, 'rejoicing', which is now reportedly relatively infrequentlyused and semi-archaic. And it could certainly have omitted ningún tipo de, which perhaps is over-emphatic.

Pex and Chips felt they should do something. Perhaps disabling the girl would earn them a bonus from Mister Spiro?

Peits e Frits achavam que deveriam fazer alguma coisa. Talvez, se desarmassem a garota, ganhassem uma bonificação do Sr Spiro.

Pex y Chips se creyeron en la obligación de hacer algo. Si conseguían reducir a la chica, tal vez el señor Spiro los recompensaría.

The English FIT original is removed from a neutral formulation: it conveys the mobsters' subjectivity through a number of indices: the sentence-initial modal adjunct, the derogatory the girl, the modal verb, and the final questionmark punctuation. Arguably the Portuguese version as worded is too neutrally by comparison, with just the initial modal as an overt subjectivity marker. The Spanish FIT translation satisfactorily "voices" Pex's and Chips's shared 
speculation, but moving tal vez, or the more informal a lo major, to sentenceinitial position would reinforce the character-voicing.

\section{Final Remarks}

In matters of linguistic theory, I am broadly aligned with integrational linguistics (Davis and Taylor 2003, Harris 1996, 1998, Toolan 1996, Hutton and Pablé2015), which rejects a conceptualisation oflinguistic communication as fixedcode telementation, or any necessary stability, across different communicational situations of form-meaning pairs. Meanings are not to be found "in" words, dictionaries, or "the language"; meanings are determined situationally, in the context-specific coordination of the communicational purposes of the parties involved. Against that radical background, it seems perfectly reasonable for me to doubt that much in the way of a "theory" of translation is possible, if by that is meant the articulation of a free-standing and general set of procedures to be followed, possibly now aided by computational corpus linguistic tools of a kind unavailable to translators in previous decades, that will reliably guide the translator in their decision-making. It seems to me that in any act of translation even of a simple sentence, multiple considerations are likely to be in play (matching or reflecting, in the target text, the source's slightly odd grammar, or its alliteration, or its conventional metaphor, or its playful tone, or its slightly archaic vocabulary). I am struck by the concord, here, with the quotation from Halliday \& Matthiessen (2004: 3) also used in Pagano's article in this thematic issue, where they remark that a text "is a rich, many-faceted phenomenon that 'means' in many different ways". As soon as you have multiple desiderata you are under pressure, as translator, to decide upon an order of priority, and accept that to meet considerations \#1 and \#2 (to your own satisfaction at least), consideration \#3 will be only half met, and \#4 and \#5 will more or less fall by the wayside. You do your best, bearing in mind your likely readers or listeners and their expectations, but also bearing in mind your obligations to the source text and its author, while never really forgetting your own interests. There is no method here; all the translator can do is review and discuss all considerations, and maybe hope for a bright idea. The process is not fundamentally different from writing an ekphrastic poem, or striking up a meaningful conversation with a stranger: some pre-existing "resources" are available in each case, but essentially one is in the business of fashioning a fresh unpredictable response.

In this article I may have seemed to dwell more on stylistic insights on children's fiction and its translation, rather than on narrative structure itself. To some extent this is inescapable: narrative structure and even narrative "features" are ultimately recognisable by their instantiating one or another stylistic feature, so it is reasonable to attend directly to those stylistic features which are central to the creation of narrative elements and structures. Thus sophisticated narratives tend to deploy para- or "complexly" repeated lexis as a means of projecting their underlying themes; similarly, para-repetitive phrases, used almost exclusively 
of just one individual in the narrative, tend to be a significant element in characterisation. Neither of these can be ignored in the practices of translation. Paying attention to such matters reflects my support for a "bottom up" approach, even where "top down" categories (like character, theme, narrative urgency, the paranormal) and their satisfactory maintenance in the translated text are the ultimate interest. I am doubtful, in relation to long fiction, that one can begin with very general narrative-structural components (such as the Labovian orientation, complicating action, evaluation, and resolution) and usefully identify these in source and target text. Long literary narratives are much more a matter of a gradually developed situation, and then sometimes unexpected changes undergone within that situation. But within that broad format of course there are local problem-solution sequences, complications building to one or several moments of crisis, which are usually highly evaluated with the telling or showing or implicating of powerful emotions (joy, anger, shame, disgust, fear, etc.); and around some of these crisis moments there may be well-developed structurings (again local) of suspense, surprise, mystery, or secrecy.

Note: I am most grateful to Professor Lincoln Fernandes (UFSC) for creating the COPA-TRAD resource, involving me in his Newton Advanced Fellowship, for his hospitality during my visits to Florianopolis, and not least for many discussions feeding into the present article; I am also most grateful to Dr Coral Calvo Maturana (University of Cadiz), Dr Eva Gomez Martinez (formerly of University of Jaen, now a Marie Curie Research Fellow here in Birmingham), and Dr Laura Hidalgo Downing (Universidad Autonoma, Madrid), for their generous advice in relation to the Spanish translation of The Eternity Code.

\section{References}

Baker, M. 1999. The Role of Corpora in Investigating the Linguistic Behaviour of Professional Translators. International Journal of Corpus Linguistics, 4(2), 281298.

Colfer, Eoin. 2003. Artemis FowlThe Eternity Code. London: Viking Press.

Colfer, Eoin. 2003. Artemis Fowl: O Código Eterno. Brazilian Portuguese transl. Alves Calado. Rio de Janeiro: Record.

Colfer, Eoin. 2003 Artemis Fowl. El Cubo B. Spanish transl.Traducción: Ana Alcaina Pérez. Montena

Davies, Mark \& Ana Maria Raposo Preto-Bay. 2007. A Frequency Dictionary of Portuguese. London: Routledge.

Davis, Hayley \& Talbot Taylor, eds. 2003. Rethinking Linguistics. London: Routledge.

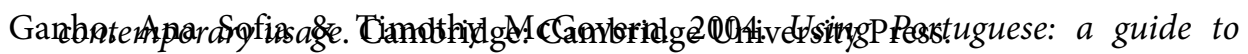


Halliday, M.A.K and C.M.I.M. Matthiessen. (2004). An Introduction to Functional Grammar. $3^{\text {rd }}$ edition. London: Hodder Arnold.

Harris, Roy. 1998. Introduction to Integrational Linguistics. Oxford: Pergamon.

Johns, T. 1991. Should you be persuaded-two samples of data-driven learning materials. ELR Journal (University of Birmingham School of English), 4, 1-16, 1991. Also available at: http://www.lexically.net/wordsmith/corpus_linguistics_links/ Tim\%20Johns\%20and\%20DDL.pdf

Lathey, Gillian, ed. (2006) The Translation of Children's Literature: A Reader. Bristol: Multilingual Matters.

Leech, Geoffrey (2008) Language in Literature: Style and Foregrounding. London: Longman.

Malmkjaer, Kirsten. 2004. Translational stylistics: Dulcken's translations of Hans Christian Andersen. Language and Literature, 13:1, 13-24.

Pablé, Adrian \& Christopher Hutton. 2015. Signs, Meaning and Experience: Integrational Approaches to Linguistics and Semiotics. Berlin: de Gruyter.

Simpson, Paul (1993) Language, Ideology and Point of View. London: Routledge.

Stephens, John. 1999. Analysing texts for children: Linguistics and stylistics. In P. Hunt, ed., Understanding children's literature, New York: Routledge, 56-68.

Toolan, Michael. 1996. Total Speech: An integrational linguistic approach to language. Chapel Hill: Duke University Press.

Toolan, Michael 2012. 'Poems: Wonderfully repetitive'. In R. Jones (ed.) Discourse and Creativity, London: Pearson, pp. 17-34.

Toolan, Michael (2015a) Why write stylistic analyses of Munro's stories? In M. Jobert and M. Toolan, eds., Stylistic Perspectives on Alice Munro's Dance of the Happy Shades, Etudes de Stylistique Anglaise, No. 8, University Jean Moulin Lyon III, 9-15.

Toolan, Michael (2015b) Poetry and poetics. In R. Jones, ed., The Routledge Handbook of Language and Creativity. London: Routledge, 231-247.

Toolan, Michael. 2016. Making Sense of Narrative Text: Situation, Repetition, and Picturing in the Reading of Short Stories. New York: Routledge.

Van Coillie, Jan and Walter P. Verschueren, eds. (2006) Children's literature in translation: challenges and strategies. Manchester: St. Jerome Publishing.

Whitlam, John. 2010. Modern Brazilian Portuguese Grammar: A Practical Guide. London: Routledge. 